\title{
Electroconvulsive Shock Differentially Increases Binding to Alpha-1 Adrenergic Receptor Subtypes in Discrete Regions of Rat Brain
}

\author{
Julie A. Blendy, ${ }^{1, a}$ Linda J. Grimm, ${ }^{2}$ David C. Perry, ${ }^{2}$ Lisa West-Johnsrud, ${ }^{1}$ and Kenneth J. Kellar ${ }^{1}$ \\ 'Department of Pharmacology, Georgetown University School of Medicine, Washington, D.C. 20007, and 'Department of \\ Pharmacology, George Washington University Medical Center, Washington, D.C. 20037
}

\begin{abstract}
Quantitative in vitro autoradiographic methods were used to examine for the effect of repeated administration of electroconvulsive shock (ECS) on binding to subtypes of the $\alpha-1$ receptor in rat brain. Rats were treated once daily for $10 \mathrm{~d}$ with ECS or sham ECS, then killed, and brains were removed and sectioned for autoradiographic analysis. Total $\alpha-1$ binding (including both $\alpha-1 \mathrm{a}$ and $\alpha-1 \mathrm{~b}$ subtypes) was assessed with $\left[{ }^{3} \mathrm{H}\right]$ prazosin; $\alpha-1 \mathrm{~b}$ binding was assessed with [ $\left.{ }^{3} \mathrm{H}\right]$ prazosin in the presence of $10 \mathrm{nM}$ WB4 101 to mask $\alpha-1 \mathrm{a}$ binding; and $\alpha-1$ a binding was assessed with [ $\left.{ }^{3} \mathrm{H}\right] \mathrm{WB} 4101$. ECS caused a significant increase in [ $\left.{ }^{3} \mathrm{H}\right]$ prazosin binding in most cortical regions; this increase was confined to a band corresponding to cortical laminae I-III. Subtype analysis indicated that the increase in cortical binding was due to an increase in binding to the $\alpha$-1b subtype. Dense $\alpha-1$ binding was detected in most thalamic nuclei; however, only 1 small area, the parafascicular nucleus, showed a significant increase in $\alpha$-1 binding following repeated ECS. The only other region where ECS was shown to significantly affect $\alpha=1$ binding was the amygdala. Binding to all regions of the amygdala except the central nuclei was increased by ECS; in the lateral amygdala, this was due primarily to an increase in $\alpha-1 b$ binding, while in the remaining regions the increase was primarily an $\alpha-1$ a phenomenon. Thus the effect of repeated ECS on $\alpha-1$ binding in rat brain was found to be confined to several specific regions of the cortex, thalamus, and amygdala. Furthermore, in each of these regions, the ECS effect was limited to 1 or the other of the 2 subtypes of the $\alpha-1$ receptor.
\end{abstract}

Repeated administration of electroconvulsive shock (ECS) increases the density of $\alpha-1$ adrenergic receptor binding sites labeled by [ $\left.{ }^{3} \mathrm{H}\right]$ prazosin in rat cerebral cortex (Vetulani et al., 1983; Stockmeier et al., 1987; Blendy et al., 1988a). However, previous studies found that ECS did not alter the density of $\alpha-1$ sites labeled by $\left[{ }^{3} \mathrm{H}\right]$ WB4 101 (Bergstrom and Kellar, 1979; Deakin et al., 1981). The difference in the effect of ECS on the binding of these 2 ligands may be due to a difference in their binding profiles. For instance, $\left[{ }^{3} \mathrm{H}\right] \mathrm{WB} 4101$ labels $5-\mathrm{HT}_{1 \mathrm{a}}$ re-

\footnotetext{
Received Jan. 18, 1990; revised March 30, 1990; accepted April 3, 1990.

The authors thank Rena Getz for excellent technical assistance. This work was funded in part by NIMH Grant MH 41819.

Correspondence should be addressed to Dr. Kenneth J. Kellar, Department of Pharmacology, Georgetown University School of Medicine, 3900 Reservoir Road, Washington, DC 20007.

a Present address: Department of Biological Chemistry, The Johns Hopkins University School of Medicine, 725 N. Wolfe Street, Baltimore, MD 21 205-2185. Copyright @ 1990 Society for Neuroscience $0270-6474 / 90 / 082580-07 \$ 03.00 / 0$
}

ceptors as well as $\alpha-1$ receptors (Norman et al., 1985), while $\left[{ }^{3} \mathrm{H}\right]$ prazosin is specific for the $\alpha-1$ receptor (Greengrass and Bremner, 1979; Miach et al., 1980). Recent studies have shown the presence of more than 1 type of $\alpha-1$ adrenergic receptor in a number of tissues, including liver (El-Refai et al., 1979), heart (Ruffolo et al., 1982), and brain (Morrow and Creese, 1986). Pharmacological characterization indicates that these receptor subtypes have equal affinities for prazosin and norepinephrine in rat tissue, but that they are distinguishable by their affinities for the $\alpha-1$ antagonists WB4101, phentolamine, 5-methylurapidil, and niguldipine (Morrow and Creese, 1986; Gross et al., 1988; Boer et al., 1989). In brain, the subtype having a higher affinity for these antagonists has been termed $\alpha-1 \mathrm{a}$, while that with a lower affinity has been termed $\alpha-1 \mathrm{~b}$ (Morrow and Creese, 1986).

The purposes of this study were 2-fold. First, we examined $\left[{ }^{3} \mathrm{H}\right]$ prazosin binding by quantitative autoradiography in sections from control and ECS-treated animals. Previous studies employed homogenate binding methods, and thus regional analysis was limited to gross brain regions that are easily dissected. Autoradiography permits examination of the effects of ECS on $\alpha-1$ adrenergic receptors in much more discrete brain regions. Second, we examined whether ECS alters 1 or both $\alpha$-1 adrenergic receptor subtypes by comparing specific binding under 3 conditions (Blendy et al., 1988b): [ $\left.{ }^{3} \mathrm{H}\right]$ prazosin (to label both $\alpha-1 \mathrm{a}$ and $\alpha-1 \mathrm{~b}$ receptors); $\left[{ }^{3} \mathrm{H}\right]$ prazosin in the presence of a 10 nM concentration of unlabeled WB4101 to mask $\alpha$-1a binding (to label $\alpha-1 \mathrm{~b}$ receptors only); and $\left[{ }^{3} \mathrm{H}\right] \mathrm{WB} 4101$ (to label $\alpha-1 \mathrm{a}$ receptors only).

\section{Materials and Methods}

Male Sprague-Dawley rats were housed in groups of 4 animals per cage under controlled lighting conditions (12:12, L:D). Rats received ECS once daily for $10 \mathrm{~d}$. Current $(150 \mathrm{~mA}, 60 \mathrm{~Hz}, 300 \mathrm{msec}$ duration) was delivered by a Wahlquist generator through orbital electrodes. Control rats were handled in the same manner, but no current was delivered. Animals were killed by decapitation $24 \mathrm{hr}$ after the last shock was delivered, and their brains were quickly removed and frozen whole on dry ice. The brains were mounted in a cryostat and $12 \mu \mathrm{m}$ coronal sections were cut from 10 regions and mounted on gelatin-coated slides and stored at $-20^{\circ} \mathrm{C}$ until use. The 10 regions corresponded to plates $6,13,21,25,29,32,37,41,49$, and 55 from the stereotaxic rat brain atlas of Paxinos and Watson (1986).

At the time of the assay, sections were thawed on a warming tray incubation at room temperature in a Krebs modified buffer (KRBM) containing $10 \mathrm{~mm} \mathrm{Na} \mathrm{NPO}_{4}, \mathrm{pH} 7.8 ; 119 \mathrm{~mm} \mathrm{NaCl} ; 6 \mathrm{~mm} \mathrm{KCl} ; 1.2$ $\mathrm{mM} \mathrm{MgSO}_{4}$; and $1.3 \mathrm{mM} \mathrm{CaCl}_{2}$ (Unnerstall et al., 1985). For the $\left[{ }^{3} \mathrm{H}\right]$ prazosin assay, sections were incubated for $1 \mathrm{hr}$ in $40 \mathrm{ml}$ chambers containing $0.9 \mathrm{nM}\left[{ }^{3} \mathrm{H}\right]$ prazosin (NEN DuPont; $82.0 \mathrm{Ci} / \mathrm{mmol}$ ) either alone or with $10 \mathrm{nM}$ WB4101. Based on equations for competitive antagonism (Tallarida and Jacobs, 1979), this concentration of WB4101 
Table 1. Effects of ECS on binding of ${ }^{3} \mathrm{H}$-prazosin $(\mathrm{fmol} / \mathrm{mg}, \pm$ SEM) to different brain regions in the presence and absence of a $10 \mathrm{nM}$ WB4101 mask

\begin{tabular}{|c|c|c|c|c|c|c|}
\hline \multirow[b]{2}{*}{ Brain region } & \multicolumn{3}{|l|}{${ }^{3} \mathrm{H}-$ Prazosin } & \multicolumn{3}{|c|}{${ }^{3} \mathrm{H}-$ Prazosin $+10 \mathrm{nM}$ WB4 101} \\
\hline & Control & ECS & $\%$ Change & Control & ECS & $\%$ Change \\
\hline \multicolumn{7}{|l|}{ Cortex } \\
\hline Orbital & $70.7 \pm 4.1$ & $85.6 \pm 3.4$ & $+21^{*}$ & $34.1 \pm 2.0$ & $42.3 \pm 3.2$ & $+24^{*}$ \\
\hline Frontal & $68.1 \pm 4.5$ & $77.9 \pm 4.2$ & +14 & $43.3 \pm 3.4$ & $54.3 \pm 3.2$ & $+25^{* * *}$ \\
\hline Parietal & $47.2 \pm 2.2$ & $53.3 \pm 3.3$ & +13 & $25.9 \pm 1.6$ & $33.8 \pm 1.2$ & $+30^{* *}$ \\
\hline Insular & $41.8 \pm 2.6$ & $54.5 \pm 3.5$ & $+30^{*}$ & $23.8 \pm 1.5$ & $32.9 \pm 2.4$ & $+38^{* *}$ \\
\hline Piriform & $55.8 \pm 3.9$ & $67.6 \pm 6.2$ & +21 & $29.9 \pm 1.8$ & $41.6+2.5$ & $+39 * *$ \\
\hline Cingulate & $61.1 \pm 4.4$ & $81.1 \pm 6.6$ & $+30^{*}$ & $31.4 \pm 2.3$ & $53.4 \pm 2.7$ & $+70^{* * *}$ \\
\hline Retrosplenial & $24.1 \pm 2.5$ & $24.6 \pm 2.0$ & +2 & $10.4 \pm .80$ & $13.8 \pm 1.2$ & $+32^{*}$ \\
\hline Perirhinal & $42.8 \pm 3.4$ & $53.9 \pm 2.9$ & $+26^{*}$ & $18.9 \pm 1.6$ & $29.4 \pm 2.6$ & $+55^{* *}$ \\
\hline Occipital & $42.5 \pm 3.4$ & $52.6 \pm 5.9$ & +24 & $19.5 \pm 2.0$ & $30.6 \pm 3.1$ & $+57^{* *}$ \\
\hline Temporal & $45.0 \pm 3.4$ & $56.4 \pm 4.3$ & +25 & $18.7 \pm 1.6$ & $32.8 \pm 1.8$ & $+76^{* * *}$ \\
\hline Entorhinal & $29.2 \pm 3.7$ & $35.8 \pm 3.5$ & +22 & $9.2 \pm 1.4$ & $15.1 \pm 1.1$ & $+64^{* *}$ \\
\hline Inner laminae & $50.2 \pm 3.0$ & $55.3 \pm 2.0$ & +10 & $29.6 \pm 2.0$ & $33.2 \pm 1.8$ & +12 \\
\hline Outer laminae & $46.6 \pm 2.2$ & $69.2 \pm 3.7$ & $+48^{* * *}$ & $22.4 \pm 1.5$ & $44.5 \pm 2.8$ & $+99^{* * *}$ \\
\hline \multicolumn{7}{|l|}{ Thalamic nuclei } \\
\hline LD & $82.5 \pm 6.3$ & $67.8 \pm 5.2$ & -18 & $63.0 \pm 6.2$ & $50.8 \pm 4.3$ & -19 \\
\hline VTH & $82.8 \pm 6.1$ & $78.6 \pm 5.6$ & -5 & $62.1 \pm 5.5$ & $55.9 \pm 4.4$ & -10 \\
\hline LPTH & $71.3 \pm 3.2$ & $75.7 \pm 4.9$ & +6 & $58.0 \pm 5.3$ & $50.8 \pm 3.3$ & -12 \\
\hline CTM & $57.7 \pm 4.2$ & $76.4 \pm 7.1$ & $+32 *$ & $38.4 \pm 6.9$ & $47.7 \pm 5.3$ & +24 \\
\hline $\mathrm{LP}$ & $82.3 \pm 3.6$ & $76.7 \pm 5.8$ & -7 & $64.9 \pm 6.1$ & $60.3 \pm 4.6$ & -7 \\
\hline DLG & $109 \pm 7.7$ & $91.3 \pm 7.3$ & -16 & $78.8 \pm 6.5$ & $73.4 \pm 6.6$ & -8 \\
\hline VIG & $16.1+2.9$ & $14.0+1.9$ & -31 & $4.7 \pm .98$ & $6.9 \pm .84$ & +46 \\
\hline MG & $58.7 \pm 4.8$ & $61.5 \pm 6.2$ & +5 & $38.3 \pm 3.9$ & $44.0 \pm 4.2$ & +15 \\
\hline \multicolumn{7}{|l|}{ Amygdala } \\
\hline CAM & $31.4 \pm 2.7$ & $30.8 \pm 3.2$ & -2 & $13.9 \pm 1.1$ & $12.2 \pm .85$ & -12 \\
\hline MAM & $30.7 \pm 1.8$ & $38.5 \pm 4.0$ & +25 & $9.1 \pm 1.2$ & $7.9 \pm .37$ & -14 \\
\hline BAM & $28.5 \pm 2.2$ & $34.2 \pm 3.4$ & +20 & $10.8 \pm 1.0$ & $12.1 \pm .52$ & +12 \\
\hline LAM & $37.1 \pm 1.9$ & $50.8 \pm 3.4$ & $+37^{* *}$ & $20.6 \pm 2.0$ & $30.0 \pm 2.1$ & $+46^{* *}$ \\
\hline AMA & $32.2 \pm 2.0$ & $42.7 \pm 2.8$ & $+32^{*}$ & $10.9 \pm 1.2$ & $13.7 \pm .99$ & +26 \\
\hline PAM & $31.8 \pm 2.8$ & $43.9 \pm 2.5$ & $+38^{* *}$ & $9.0 \pm 1.1$ & $11.1 \pm .54$ & +23 \\
\hline Hypothalamus & $32.5 \pm 1.9$ & $35.6 \pm 2.0$ & +9 & $13.4 \pm 1.3$ & $12.4 \pm 1.0$ & -7 \\
\hline Hippocampus & $19.1 \pm 2.0$ & $20.9 \pm 1.5$ & +9 & $6.6 \pm .80$ & $7.2 \pm .62$ & +8 \\
\hline Ventral hippocampus & $23.3 \pm 3.2$ & $20.6 \pm 2.7$ & -11 & $4.9 \pm .81$ & $6.5 \pm .67$ & +34 \\
\hline Mamm. hypothalamus & $26.4 \pm 2.8$ & $28.8 \pm 3.8$ & +9 & $13.0 \pm 1.6$ & $12.8 \pm 1.3$ & 0 \\
\hline Interpeduncular nucleus & $25.7 \pm 3.7$ & $28.7 \pm 2.3$ & +12 & $14.3 \pm 3.7$ & $17.3 \pm 1.4$ & +21 \\
\hline Central gray & $27.0 \perp 3.8$ & $20.1 \perp 2.3$ & -25 & $5.7 \pm .56$ & $5.3 \pm 1.1$ & -7 \\
\hline Rostral linear raphe & $18.0 \pm 3.5$ & $15.8 \pm 2.8$ & -12 & $5.5 \pm .72$ & $4.9 \pm .73$ & -11 \\
\hline Median raphe & $24.8+1.4$ & $22.9+3.9$ & -7 & $9.6+.67$ & $9.5+1.4$ & 0 \\
\hline Dorsal raphe & $43.2 \pm 4.4$ & $42.7 \pm 4.3$ & -1 & $22.3 \pm 1.6$ & $21.0 \pm 1.6$ & -6 \\
\hline Locus ceruleus & $23.8 \pm 2.5$ & $23.8 \pm 2.3$ & 0 & $6.2 \pm 1.2$ & $5.1 \pm .70$ & -18 \\
\hline Inferior colliculus & $5.0 \pm .70$ & $3.9 \pm 1.1$ & -24 & $2.0 \pm .65$ & $1.3 \pm .81$ & -38 \\
\hline Cerebellum & $22.4 \pm 2.3$ & $25.1 \pm 2.3$ & +12 & $8.7 \pm .99$ & $10.0 \pm 1.3$ & +14 \\
\hline
\end{tabular}

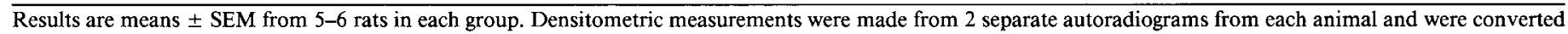

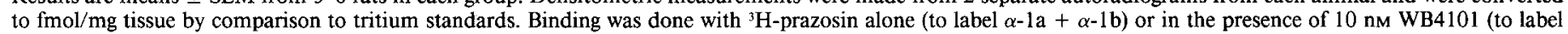

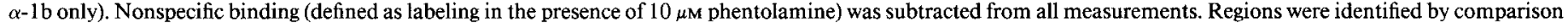

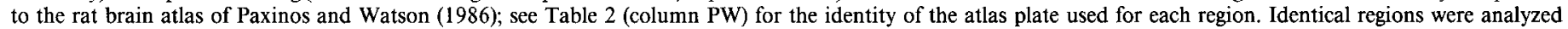

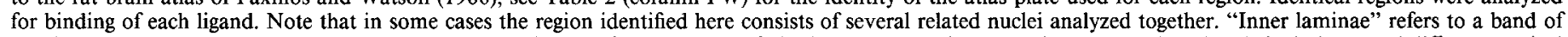

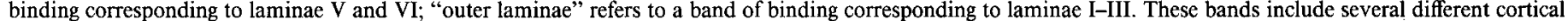

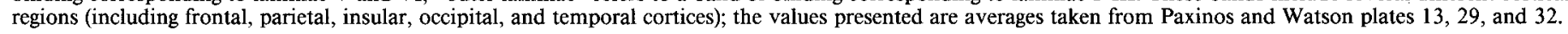

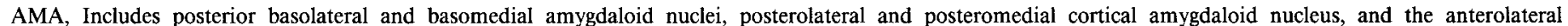

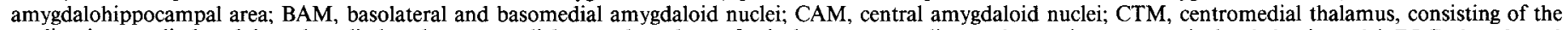

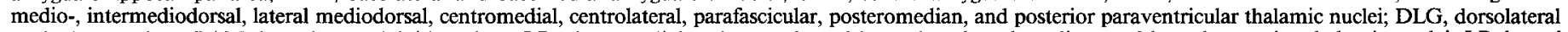

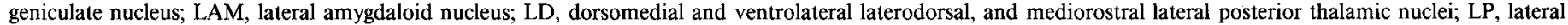

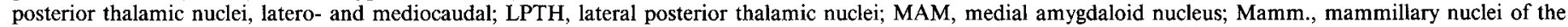

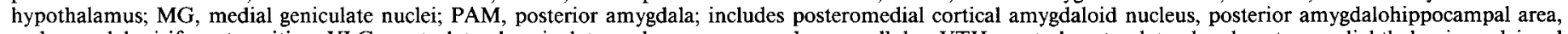

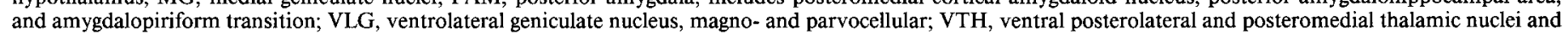
posterior thalamic nuclear group.

${ }^{*} p<0.05 ;{ }^{* *} p<0.01 ; * * * p<0.001$. 

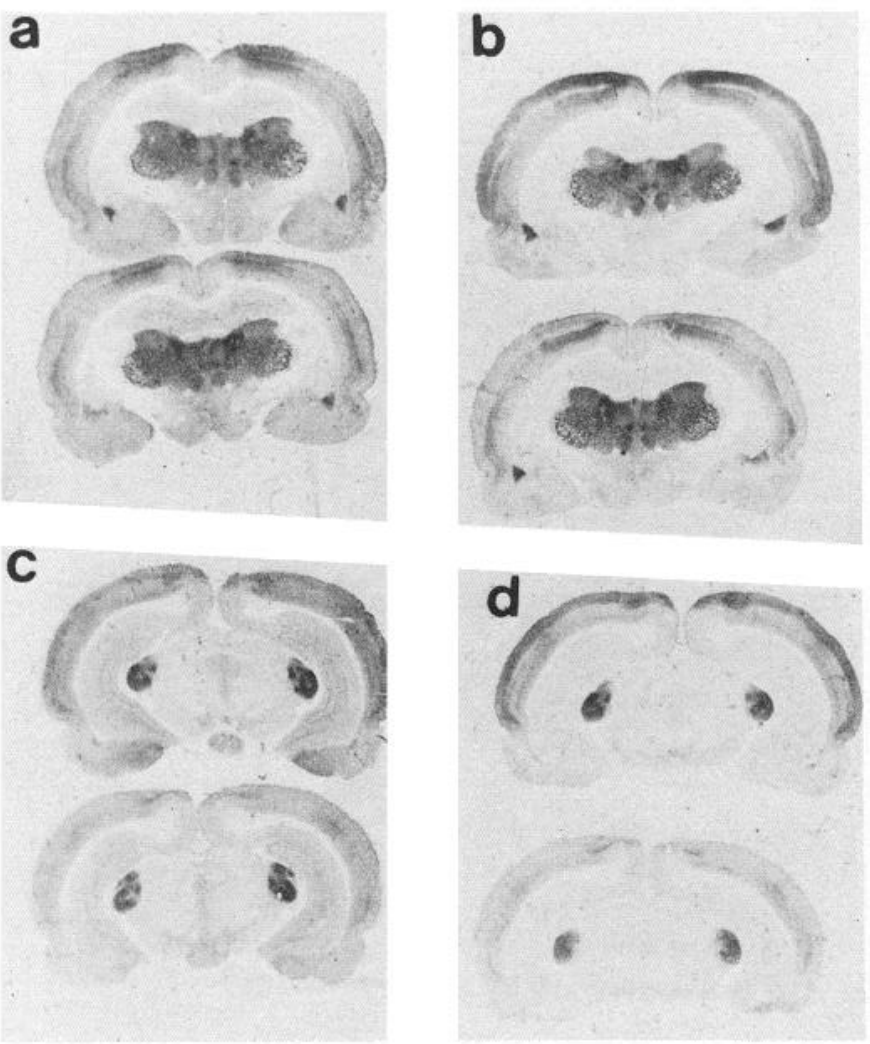

Figure 1. Autoradiographic images of $\left[{ }^{3} \mathrm{H}\right]$ prazosin binding to rat coronal brain slices, in 2 regions each with 2 conditions. A composite negative was made from the 4 images, which was then used to print the final image shown here. Dark grains indicate the presence of radioactive ligand. In each pair of sections, the top section is from an ECS-treated animal, and the bottom section is from a control animal. Each pair was mounted on the same slide and processed for binding together. $a$, Total $\left[{ }^{3} \mathrm{H}\right]$ prazosin binding $(=\alpha-1 \mathrm{a}+\alpha-1 \mathrm{~b}$ binding); section is equivalent to Paxinos and Watson (1986) plates 29 (PW 29). $b$, Same region as in $a$, but binding with a $10 \mathrm{nM}$ WB4 101 mask, showing $\alpha$-1b binding. $c$, Total $\left[{ }^{3} \mathrm{H}\right]$ prazosin binding; from PW 41. $d$, Same region as in $c$, but with a $10 \mathrm{nM}$ WB4101 mask, showing $\alpha$-1b binding.

can be calculated to occupy $86 \%$ of $\alpha$-1a receptors and $18 \%$ of $\alpha-1 \mathrm{~b}$ receptors. Adjacent sections were incubated with radioligand plus 10 $\mu \mathrm{M}$ phentolamine to determine nonspecific binding. Following incubation, sections were rinsed twice for $5 \mathrm{~min}$ in ice-cold KRBM, and then dipped briefly in ice-cold water. For the [ $\left.{ }^{3} \mathrm{H}\right]$ WB4 101 assay, 0.7 nM [ $\left.{ }^{3} \mathrm{H}\right]$ WB4 101 (NEN; $\left.22.8 \mathrm{Ci} / \mathrm{mmol}\right)$ was incubated for $30 \mathrm{~min}$ at room temperature in the presence of $100 \mathrm{~nm}$ serotonin (5-hydroxytryptamine (5-HT) creatine sulfate). This concentration has no effect on $\alpha-1$ binding (as measured by $\left[{ }^{3} \mathrm{H}\right]$ prazosin; J. A. Blendy, unpublished data), but will inhibit $\left[{ }^{3} \mathrm{H}\right] \mathrm{WB} 4101$ binding to the 5 -HT la receptor. Incubation was followed by 32 -min rinses in ice-cold buffer and a final brief rinse in distilled water. Nonspecific binding of $\left[{ }^{3} \mathrm{H}\right]$ WB4 101 was determined in adjacent sections in the presence of $100 \mathrm{nM}$ prazosin. After washing, slides were rapidly dried with cool, dry air and left in a vacuum desiccator overnight. Slides were then apposed to tritium-sensitive film (LKB Ultrofilm) along with tritium standards (Amersham $\mu$ Scales).

After approximately 3 months' exposure, the film was developed in Kodak D-19, and specific binding was analyzed using a RAS1000 densitometry system (Loats/Amersham). Optical density was converted to $\mathrm{fmol} / \mathrm{mg}$ tissue by comparison with a standard curve constructed from optical densities of tritium standards, using the specific activities of the 2 radioligands. Nonspecific binding was subtracted from all values. Brain areas were identified by comparing autoradiographic images with appropriate plates from the rat brain atlas of Paxinos and Watson (1986). Within the amygdala and thalamus, we delineated subregions based on the actual pattern of binding observed. In most cases these subregions consisted of several related nuclei or subnuclei. The specific anatomical description of the subregions is given in the legend to Table 1.

\section{Results}

Representative autoradiographic images of $\left[{ }^{3} \mathrm{H}\right]$ prazosin binding to 2 different coronal planes are shown in Figure 1, and the results of quantitative densitometric analysis of $\left[{ }^{3} \mathrm{H}\right]$ prazosin binding to selected brain regions are given in Table 1 . The highest levels of $\left[{ }^{3} \mathrm{H}\right]$ prazosin binding were seen in the thalamus and in the orbital, frontal, cingulate, and piriform cortex. Of the 11 cortical regions surveyed, $\left[{ }^{3} \mathrm{H}\right]$ prazosin binding showed a statistically significant increase following ECS only in the cingulate, orbital, insular, and perirhinal cortex (Table 1). Cortical binding of $\left[{ }^{3} \mathrm{H}\right]$ prazosin was concentrated in a dense band, previously identified as corresponding to lamina V (Rainbow and Biegon, 1983). However, in animals subjected to repeated ECS, an equally dense band of $\left[{ }^{3} \mathrm{H}\right]$ prazosin binding was seen (Fig. 1), which appeared to correspond to laminae I-III. We analyzed these bands separately over multiple cortical regions in 3 separate plates, identified as "inner laminae" (equivalent to laminae $\mathrm{V}$ and VI) and "outer laminae" (equivalent to laminae I-III). The increase in cortical binding after repeated ECS was entirely confined to the outer laminae. Of all other brain regions surveyed, the only ones that showed statistically significant increases in $\left[{ }^{3} \mathrm{H}\right]$ prazosin binding with ECS were the posterior and lateral amygdaloid nuclei (AMA, LAM, and PAM in Table 1; see below for details) and the centromedial (CTM) thalamic nuclei (consisting of the parafascicular, paraventricular, posteromedian, intermediodorsal, and dorsal thalamic nuclei; the increase appeared to be confined to the parafascicular nucleus).

In order to determine whether the effect of ECS on $\left[{ }^{3} \mathrm{H}\right]$ prazosin binding was subtype selective, we analyzed adjacent sections in the presence of $10 \mathrm{nM}$ WB4 101 to block binding of $\left[{ }^{3} \mathrm{H}\right]$ prazosin to $\alpha$-1 a sites; the resultant binding should be predominantly to the $\alpha$-1b subtype only (Fig. 1, $b, d$; Fig. 2b). Any increase in $\left[{ }^{3} \mathrm{H}\right]$ prazosin binding by ECS that was the result of an increase in $\alpha-1 \mathrm{~b}$ receptors only would result in a proportionally greater increase in binding under these conditions. This was the result obtained in all regions on the cortex (Table 1): $\left[{ }^{3} \mathrm{H}\right]$ prazosin binding was increased by $20-30 \%$ in ECS animals, while in the presence of $10 \mathrm{nM}$ WB4101, the increases ranged from 30 to $99 \%$, and all increases were statistically significant. The laminar specificity was even more marked in the presence of a WB4101 mask: binding in the outer laminae increased $99 \%$ after ECS, with no change in the inner laminae. These findings confirm and extend our homogenate studies which found that ECS selectively increases the $B_{\max }$ of the $\alpha$-1b subtype in rat cortex (Blendy et al., 1989). In the thalamus and amygdala the effect of including WB4101 in the binding assay for $\left[{ }^{3} \mathrm{H}\right]$ prazosin was different than in the cortex. The increases in $\left[{ }^{3} \mathrm{H}\right]$ prazosin binding seen in the CTM, AMA, and PAM were smaller and nonsignificant in the presence of WB4101. An exception was the LAM, where $\left[{ }^{3} \mathrm{H}\right]$ prazosin binding was increased by ECS $46 \%$ in the presence of $10 \mathrm{nM}$ WB4 101 compared to a $37 \%$ increase in ECS-treated animals when measured with $\left[{ }^{3} \mathrm{H}\right]$ prazosin alone. No other areas of the brain that were analyzed showed ECSinduced increases in $\left[{ }^{3} \mathrm{H}\right]$ prazosin binding performed in the presence of WB4101.

Low concentrations of $\left[{ }^{3} \mathrm{H}\right] \mathrm{WB} 4101$ in the presence of a serotonin mask permit direct measurement of $\alpha$-1a receptors. Figure 2 shows autoradiographic images from 4 adjacent sections, comparing the binding of $\left[{ }^{3} \mathrm{H}\right]$ prazosin alone $(\alpha-1 \mathrm{a}+\alpha-1 \mathrm{~b})$, 

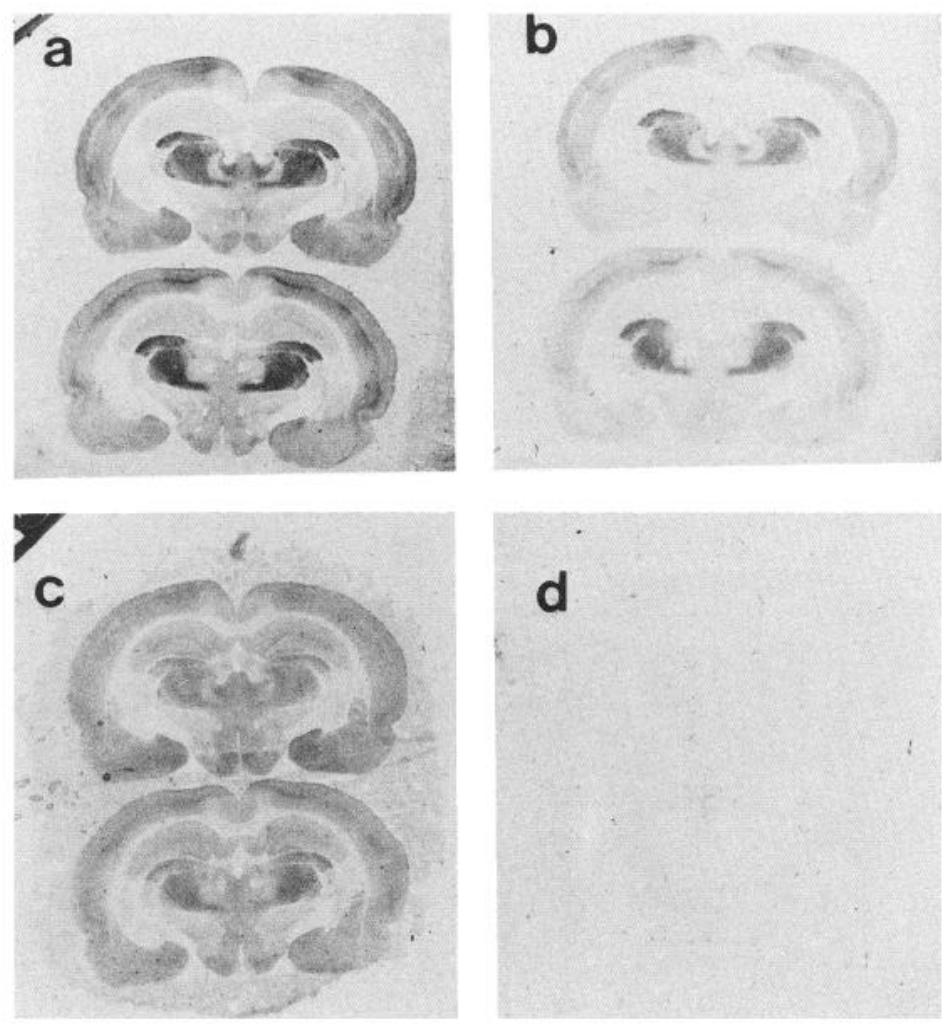

Figure 2. Autoradiographic images of $\left[{ }^{3} \mathrm{H}\right]$ prazosin and $\left[{ }^{3} \mathrm{H}\right]$ WB4 101 binding to rat coronal brain slices. A composite negative was made from the 4 images, which was then used to print the final image shown here. Dark grains indicate the presence of radioactive ligand. In each pair of sections, the top section is from an ECS-treated animal, and the bottom section is from a control animal. Each pair was mounted on the same slide and processed for binding together. One brain region is shown (PW 33), with 4 different conditions. $a$, Total $\left[{ }^{3} \mathrm{H}\right]$ prazosin binding $(=\alpha-1 \mathrm{a}+\alpha-1 \mathrm{~b}$ binding). $b,\left[{ }^{3} \mathrm{H}\right]$ Prazosin binding with a 10 nM WB4101 mask, showing $\alpha-1 b$ binding. $c,\left[{ }^{3} \mathrm{H}\right]$ WB4 101 binding, showing $\alpha$-1a binding. $d,\left[{ }^{3} \mathrm{H}\right]$ Prazosin binding, with $10 \mu \mathrm{M}$ phentolamine, showing nonspecific binding ("blank"). Autoradiographic images of $\left[{ }^{3} \mathrm{H}\right]$ WB4 101 binding in the presence of $10 \mu \mathrm{M}$ phentolamine were essentially equivalent to this image (not shown). $\left[{ }^{3} \mathrm{H}\right]$ prazosin plus $10 \mathrm{nM}$ WB4101 $(\alpha-1 \mathrm{~b})$, and $\left[{ }^{3} \mathrm{H}\right]$ WB4101 $(\alpha-$ 1a). Nonspecific binding of $\left[{ }^{3} \mathrm{H}\right]$ prazosin is also shown. The nonspecific binding of $\left[{ }^{3} \mathrm{H}\right] \mathrm{WB} 4101$ is not shown; these images were similar in appearance to the $\left[{ }^{3} \mathrm{H}\right]$ prazosin "blanks." Values for $\left[{ }^{3} \mathrm{H}\right]$ WB4 101 binding to different brain regions measured by quantitative autoradiography are given in Table 2 . Unlike $\left[{ }^{3} \mathrm{H}\right]$ prazosin binding, no significant laminar binding was apparent. $\left[{ }^{3} \mathrm{H}\right] \mathrm{WB} 4101$ binding was significantly increased $(56 \%)$ after ECS in only 1 cortical area, the entorhinal cortex. In contrast, all amygdaloid areas examined, with the exception of the central amygdaloid nucleus, showed increases of from 27 to $53 \%$ in $\left[{ }^{3} \mathrm{H}\right]$ WB4 101 binding after ECS. No other brain regions analyzed showed appreciable changes in $\left[{ }^{3} \mathrm{H}\right] \mathrm{WB} 4101$ binding in ECS animals.

\section{Discussion}

Interpretation of early studies of the effect of repeated ECS on $\alpha-1$ binding was hindered by a lack of knowledge of the subtype selectivity of the ligands employed. More recent studies revealed that the effect of ECS in cortex was limited to an increase in the $\alpha$-1b subtype (Blendy et al., 1988b, 1989). The current study confirms this finding in cortex and extends it by demonstrating that the increase is confined to a band of binding in the outermost laminae of the cortex. Studies using homogenate binding techniques in dissected regions of rat brain failed to detect any effect of repeated ECS on $\alpha-1$ binding in regions other than cortex (Stockmeier et al., 1987; Nowak and Przegalinski, 1988). Autoradiography reveals that while $\alpha-1$ binding in most brain regions is indeed unaffected by ECS, there are several specific regions in the amygdala and thalamus where $\alpha-1$ binding is increased. Furthermore, by employing binding conditions selective for 1 or the other subtypes of the $\alpha-1$ receptor, we have found that the increases were subtype-specific in the different regions.

In the cortex, the most remarkable finding was the distinct laminar selectivity of the ECS effects. Autoradiography of $\left[{ }^{3} \mathrm{H}\right]$ prazosin (Rainbow and Biegon, 1983) and [ $\left.{ }^{125} \mathrm{I}\right] \mathrm{HEAT}$ (Jones et al., 1985) in rat brain clearly shows that the binding in cortex is largely present in a dense double band corresponding to laminae $\mathrm{Va}$ and $\mathrm{Vc}$. This pattern was also seen in the present study (i.e., see control (bottom) sections in Fig. 1). However, repeated ECS had no effect on this band; rather, a new dense band of binding was seen that appeared to correspond to laminae I-III (see top sections in Fig. 1). Noradrenergic fibers that innervate the cortex arise exclusively from the nucleus locus ceruleus (Foote et al., 1983). This innervation also shows a laminar distribution, with dense terminal fields in laminae V-VI and laminae II-III (Parnavelas and Papadopoulos, 1989). Lindvall et al. (1978) reported that norepinephrine fibers were most dense in lamina I, but noted that these fibers have a "nonterminal appearance." It is surprising that the effects of a global stimulus such as ECS would be entirely limited to 1 of these fields. This result is in contrast to the effects of another global stimulus, reserpine, which we have found to increase $\left[{ }^{3} \mathrm{H}\right]$ prazosin binding roughly equally in both inner and outer cortical laminae (Grimm et al., 1989). Interestingly, no such laminar banding was detected in autoradiograms of $\left[{ }^{3} \mathrm{H}\right] \mathrm{WB} 4101$ binding (see Fig. $2 c$ ), suggesting that $\alpha$-1a receptors are more homogeneously distributed throughout the cortex.

Previous studies as well as this one on the effects of ECS on $\left[{ }^{3} \mathrm{H}\right]$ prazosin binding have shown modest (i.e., 20-30\%) increases in cortical binding. Inclusion of a $10 \mathrm{nM}$ WB4101 mask resulted in much higher increases (30-99\%). In rat cortical membranes, $\alpha$-1a sites comprise approximately one-third and $\alpha-1 \mathrm{~b}$ 
Table 2. Effects of ECS on binding of $\left[{ }^{3} \mathrm{H}\right] \mathrm{WB} 4101$ ( $\left.\mathrm{fmol} / \mathrm{mg}\right)$ to different brain regions

\begin{tabular}{|c|c|c|c|c|}
\hline \multirow[b]{2}{*}{ Brain region } & \multirow[b]{2}{*}{ PW } & \multicolumn{2}{|c|}{ Binding \pm SEM } & \multirow[b]{2}{*}{$\%$ Change } \\
\hline & & Control & ECS & \\
\hline \multicolumn{5}{|l|}{ Cortex } \\
\hline Orbital & 6 & $50.6 \pm 8.6$ & $50.7 \pm 6.5$ & 0 \\
\hline Frontal & 13 & $64.5 \pm 5.4$ & $61.9 \pm 5.7$ & -4 \\
\hline Parietal & 13 & $47.4 \pm 4.3$ & $43.6 \pm 4.8$ & -8 \\
\hline Insular & 13 & $45.4 \pm 4.8$ & $52.8 \pm 6.8$ & +16 \\
\hline Piriform & 13 & $45.6 \pm 5.0$ & $56.2 \pm 6.6$ & +23 \\
\hline Cingulate & 13 & $64.8 \pm 4.5$ & $69.2 \pm 6.3$ & +7 \\
\hline Retrosplenial & 29 & $34.2 \pm 1.3$ & $29.9 \pm 2.0$ & -13 \\
\hline Perirhinal & 29 & $43.3 \pm 3.7$ & $48.6 \pm 1.5$ & +12 \\
\hline Occipital & 37 & $44.9 \pm 3.2$ & $40.4 \pm 2.8$ & -10 \\
\hline Temporal & 37 & $44.0 \pm 2.9$ & $45.4 \pm 4.4$ & 13 \\
\hline Entorhinal & 37 & $24.7 \pm 1.9$ & $38.5 \pm 4.4$ & $+56^{*}$ \\
\hline Inner laminae & $13,29,32$ & $46.7 \pm 1.9$ & $46.1 \pm 3.3$ & -1 \\
\hline Outer laminae & $13,29,32$ & $52.2 \pm 2.4$ & $56.2 \pm 2.6$ & +8 \\
\hline \multicolumn{5}{|l|}{ Thalamic nuclei } \\
\hline LD & 29 & $57.9 \pm 2.3$ & $48.3 \pm 5.4$ & -17 \\
\hline VTH & 29 & $52.6 \pm 2.7$ & $50.7 \pm 3.7$ & -4 \\
\hline LPTH & 32 & $53.7 \pm 3.5$ & $52.4 \pm 4.4$ & -2 \\
\hline CTM & 32 & $5.7 .4 \pm 3.9$ & $62.1 \pm 4.5$ & +8 \\
\hline LP & 37 & $61.8 \pm 7.6$ & $49.2 \pm 6.6$ & -20 \\
\hline DLG & 37 & $65.9 \pm 5.8$ & $54.4 \pm 9.0$ & -18 \\
\hline VLG & 37 & $16.4 \pm 2.2$ & $14.6 \pm 2.8$ & -11 \\
\hline $\mathrm{MG}$ & 37 & $38.5 \pm 7.2$ & $36.1 \pm 4.7$ & -6 \\
\hline \multicolumn{5}{|l|}{ Amygdala } \\
\hline CAM & 29 & $38.6 \pm 4.5$ & $41.8 \pm 2.2$ & +8 \\
\hline MAM & 29 & $41.0 \pm 4.9$ & $55.7 \pm 2.4$ & $+36^{*}$ \\
\hline BAM & 29 & $36.0 \pm 3.8$ & $45.6 \pm 2.4$ & $+27^{*}$ \\
\hline LAM & 29,32 & $42.4 \pm .99$ & $53.4 \pm 3.9$ & $+26^{*}$ \\
\hline AMA & 32 & $38.9 \pm 3.6$ & $52.8 \pm 3.6$ & $+35^{*}$ \\
\hline PAM & 37,41 & $35.0 \pm 3.3$ & $54.8 \pm 4.5$ & $+56^{* * *}$ \\
\hline Hypothalamus & 32 & $40.0 \pm 2.6$ & $46.0 \pm 3.9$ & +15 \\
\hline Hippocampus & 32 & $29.4 \pm 1.5$ & $29.9 \pm 3.6$ & +2 \\
\hline Ventral hippocampus & 37 & $28.7 \pm 2.4$ & $27.9 \pm 3.4$ & -3 \\
\hline Mamm. hypothalamus & 37 & $20.0 \pm 3.4$ & $32.0 \pm 5.1$ & +60 \\
\hline Interpeduncular nucleus & 41 & $21.1 \pm 1.9$ & $25.9 \pm 2.2$ & +23 \\
\hline Central gray & 41 & $28.5 \pm 1.7$ & $26.1 \pm 1.4$ & -8 \\
\hline Rostral linear raphe & 41 & $16.5 \pm 2.5$ & $21.5 \pm 2.8$ & +31 \\
\hline Median raphe & 49 & $15.8 \pm 2.5$ & $23.4 \pm 3.7$ & +48 \\
\hline Dorsal raphe & 49,55 & $43.6 \pm 4.0$ & $39.1 \pm 2.5$ & -10 \\
\hline Locus ceruleus & 55 & $40.8 \pm 5.0$ & $25.7 \pm 5.4$ & -37 \\
\hline Inferior colliculus & 55 & $21.6 \pm 2.9$ & $15.8 \pm 3.9$ & -27 \\
\hline Cerebellum & 55 & $35.9 \pm 4.9$ & $23.6 \pm 5.5$ & -34 \\
\hline
\end{tabular}

Results are means \pm SEM from 5-6 rats in each group. Densitometric measurements were made from 2 separate autoradiograms from each animal and were converted to $\mathrm{fmol} / \mathrm{mg}$ tissue by comparison to tritium standards. Binding was done with $\left[{ }^{3} \mathrm{H}\right]$ WB4 101 ; nonspecific binding (defined as labeling in the presence of 100 nm prazosin) was subtracted from all measurements. Regions were identitied by comparison to the rat brain atlas of Paxinos and Watson (1986); the atlas plate used for each region is noted in column PW. For abbreviations, see Table 1.

${ }^{*} p<0.05 ;{ }^{* * *} p<0.001$.

sites comprise approximately two-thirds of the total population of $\alpha-1$ receptors (Morrow and Creese, 1986; Wilson and Minneman, 1989; Blendy et al., unpublished observations). A $10 \mathrm{~nm}$ concentration of WB4101 should occupy $86 \%$ of $\alpha-1$ a sites and $18 \%$ of $\alpha-1 \mathrm{~b}$ sites. Thus these binding conditions should yield a preparation highly enriched in $\alpha$-1b sites. Therefore, it is likely that the effect of ECS is confined to the $\alpha-1 \mathrm{~b}$ subtype, explaining the much larger increase in $\left[{ }^{3} \mathrm{H}\right]$ prazosin binding in the presence of WB4101. This conclusion is greatly strengthened by the finding that cortical $\alpha$-1a sites labeled directly by [ $\left.{ }^{3} \mathrm{H}\right]$ WB4 101 were not affected by ECS, as has been previously reported (Bergstrom and Kellar, 1979; Deakin et al., 1981; Kellar et al., 1981). One curious exception to this was the entorhinal cortex, which showed a $56 \%$ increase in $\left[{ }^{3} \mathrm{H}\right] \mathrm{WB} 4101$ binding after ECS. The ento- 
rhinal cortex has several distinctive features: this region had one of the lowest absolute levels of both $\left[{ }^{3} \mathrm{H}\right]$ prazosin and $\left[{ }^{3} \mathrm{H}\right]$ WB4 101 binding, but it had the highest proportion of $\alpha-1 \mathrm{a}$ binding in the cortex. Also, the pyramidal cell layer $\mathrm{V}$ is missing from the entorhinal cortex (Jones et al., 1985), and the $\left[{ }^{3} \mathrm{H}\right]$ prazosin laminar binding pattern was not seen in this region. Finally, this region is immediately adjacent to the posterior amygdala, a region with a high proportion of $\alpha$-1a sites, and where ECS also increased $\left[{ }^{3} \mathrm{H}\right] \mathrm{WB} 4101$ binding $56 \%$.

While the thalamus has the greatest density of $\alpha-1$ receptors in rat brain, previous studies have found no effect in this region after repeated ECS (Nowak and Przegalinski, 1988). In the current study, we also found no effect of ECS on thalamic binding, with the exception of the central medial nucleus, which showed a $32 \%$ increase in total $\left[{ }^{3} \mathrm{H}\right]$ prazosin binding. It is puzzling that this increase was not seen in sections incubated with $10 \mathrm{~nm}$ WB4 101 to block $\alpha$-1a binding or in [ $\left.{ }^{3} \mathrm{H}\right]$ WB4 101 binding. Examination of Figure 2 shows a clearly visible increase in binding density in a discrete region that appears to be largely confined to the parafascicular nucleus in all 3 images (Fig. 2, $a, b$, and c). However, examination of the corresponding autoradiograms from the other animals included in the quantitative analysis revealed that in many cases the sections were cut in a slightly more rostral plane than the image shown in Figure 2, and in these sections the parafascicular nucleus is not present in the region outlined for quantitative analysis. Thus we are unable to give a quantitative result; however, we have qualitative evidence for an increase in both $\alpha-1 \mathrm{a}$ and $\alpha-1 \mathrm{~b}$ receptor binding by ECS in the parafascicular thalamic nucleus. The size of this increase may well have been greater than $32 \%$, as the effect would have been "diluted" by inclusion in the analysis of several areas that showed no increases. In contrast to this finding that ECS has no effect on most of the $\alpha$-1 binding in the thalamus, thalamic binding of [ $\left.{ }^{3} \mathrm{II}\right]$ prazosin is significantly increased following chronic reserpine (Grimm et al., 1989).

The other region that showed an effect of FCS on $\alpha-1$ binding was the amygdala, where a complex pattern was observed. Binding to the central nuclei (medial and lateral divisions of the central amygdaloid nucleus) was unaffected by ECS. Binding to the lateral amygdaloid nuclei was significantly increased by ECS; this increase was due largely to an increase in $\alpha-1 \mathrm{~b}$ binding, but with a component of increase from $\alpha$-1a binding as well. The remaining areas surveyed all showed an increase in binding with ECS, but in contrast to the lateral nucleus, the increase was almost entirely confined to the $\alpha$-la site (Table 2). The central nucleus is the only area where $\alpha-1$ binding is not affected by ECS. Norepinephrine fibers from the locus ceruleus extensively innervate the amygdala, particularly the basal and central nuclei (Swanson and Hartman, 1975). The central nuclei also has high levels of tyrosine hydroxylase and norepinephrine (see Jones et al., 1985). The lateral nucleus is not distinguished by the level of its noradrenergic innervation; nevertheless, it stood out as having the highest $\alpha-1$ binding in the amygdala (Jones et al., 1985 , and this study), and as having the highest proportion of $\alpha-1 \mathrm{~b}$ binding.

Electroconvulsive therapy (ECT) is an important treatment for severe depression. The mechanism of ECT in relieving symptoms of depression is not known, but may well involve alterations in biogenic amine neurotransmission. Interestingly, several studies have found that chronic administration of tricyclic antidepressant drugs does not cause an increase in the binding of $\left[{ }^{3} \mathrm{H}\right]$ prazosin to rat brain homogenates (Menkes et al., 1983;
Stockmeier et al., 1987) (although this has been disputed; see Vetulani et al., 1983). Tricyclic antidepressants have relatively high affinity for $\alpha-1$ receptors and would be expected to occupy a large fraction of these receptors under normal clinical circumstances (Stockmeier et al., 1987). These differences in effects of antidepressant drugs and ECS on $\alpha-1$ receptors may underlie some of the differences among clinical responses to these 2 depression treatments. For instance, patients undergoing ECT respond in a shorter time period than with drug treatment, and ECT has been found to be particularly useful in patients who have demonstrated a previous resistance to drug therapy (Crowe, 1984).

A striking finding of the current study is that the effects on alpha-1 receptors from a global stimulus like ECS have a discrete anatomical localization. Many areas involved in noradrenergic transmission in the brain showed no significant effect from repeated ECS, including most of the thalamus, the locus ceruleus, hippocampus, and hypothalamus. While the effects of ECS on $\alpha-1$ binding are anatomically limited to specific brain structures, it is not known what functional role these areas serve in relation to the etiology or treatment of depression. The cortex may play a role in controlling mood and affect; if so, the current findings suggest the possibility of a laminar specificity in this activity. The amygdala is a complicated structure, receiving primarily cortical input, with efferents to the hypothalamus, cortex, and thalamus. It is involved in autonomic and neuroendocrine regulation, and numerous studies indicate that the amygdala plays an important role in governing behavior related to emotional states (see Isaacson, 1982). For instance, monkeys with amygdala lesions do not function normally as members of their social group; their behavior resembles that of depressed humans in some ways and suggests a role for the amygdala in regulation of affect (Kling, 1972; Gloor, 1978). The current finding that the amygdala is one of the few regions to show an effect by ECS on $\alpha-1$ receptors is consistent with such a role and suggests a possible site of action for the antidepressant effects of ECT. The parafascicular thalamic nucleus is known to play a role in nociception (Reyes-Vazquez et al., 1986), but its possible significance in depression and mood is not known.

In summary, we have used quantitative autoradiography to determine the effect of repeated ECS on increasing binding to $\alpha-1 \mathrm{a}$ and $\alpha-1 \mathrm{~b}$ adrenergic receptors in rat brain. The effects are quite limited anatomically, occurring only in the outer laminae of the cortex, the parafascicular thalamic nucleus, and all but the central nucleus of the amygdala. Furthermore, the effect shows specificity for the $2 \alpha-1$ subtypes in different regions: in cortex, only the $\alpha-1 \mathrm{~b}$ subtype is increased; in the parafascicular nucleus and lateral amygdala, both subtypes are increased; in the other amygdaloid nuclei only the $\alpha$-l a subtype is affected. Identification of the specific brain regions affected by ECS may contribute to the further understanding of the therapeutic effect of this important treatment for depression.

\section{References}

Bergstrom DA, Kellar KJ (1979) Effect of electroconvulsive shock on monoaminergic receptor binding sites in rat brain. Nature 278:464 466.

Blendy JA, Stockmeier CA, Kellar KJ (1988a) Electroconvulsive shock and reserpine increase alpha-1-adrenoceptor binding sites but not norepinephrine-stimulated phosphoinositide hydrolyses in rat brain. Eur J Pharmacol 156:267-270.

Blendy JA, Grimm LJ, Perry DC, Kellar KJ (1988b) Differential regulation of alpha-1-adrenergic receptor subtypes by electroconvulsive shock and reserpine. Neurosci Abstr 14:1052. 
Blendy JA, West-Johnsrud L, Perry DC, Kellar KJ (1989) Electroconvulsive shock increases one subtype of alpha-1 adrenergic receptors in selective areas of rat brain. Neurosci Abstr 15:1319.

Boer R, Grassegger A, Schudt C, Glossman H (1989) (+)Niguldipine binds with very high affinity to calcium channels and to a subtype of alpha-1-adrenoceptors. Eur J Pharmacol (Mol Pharmacol Sec) 172: 131-145.

Crowe RR (1984) Electroconvulsive therapy-a current perspective. N Engl J Med 311:163-167.

Deakin JFW, Owen F, Cross AJ, Sahwond MJ (1981) Studies on possible mechanisms of action of electroconvulsive therapy; effects of repeated electrically induced seizures on rat brain receptors for monoamines and other neurotransmitters. Psychopharmacology 73: 345.

El-Refai MF, Blackmore PF, Exton JH (1979) Evidence for two alphaadrenergic binding sites in liver plasma membrane. J Biol Chem 254: $4375-4386$.

Foote SL, Bloom FE, Aston-Jones G (1983) The nucleus locus coeruleus. New evidence of anatomical and physiological specificity. Physiol Rev 63:844-914.

Gloor P (1978) Inputs and outputs of the amygdala: what the amygdala is trying to tell the rest of the brain. In: Limbic mechanisms (Livingston KE, Hornykiewicz O, eds), pp 189-210. New York: Plenum.

Greengrass P, Bremner R (1979) Binding characteristics of ${ }^{3} \mathrm{H}$-prazosin to rat brain alpha-adrenergic receptors. Eur J Pharmacol 55: 323-326.

Grimm LJ, Blendy JA, West-Johnsrud L, Perry DC, Kellar KJ (1989) Differential regulation of alpha-1 adrenergic receptors by reserpine. Neurosci Abstr 15:1319.

Gross G, Hanft G, Rugevics F (1988) 5-Methylurapidil discriminates between subtypes of the alpha-1-adrenoceptor. Eur J Pharmacol 151: 333-335.

Isaacson RL (1982) The limbic system, 2nd ed. New York: Plenum.

Jones LS, Gauger LL, Davis JN (1985) Anatomy of brain alpha-1 adrenergic receptors: in vitro autoradiography with ${ }^{125}$ I-HEAT. J Comp Neurol 231:190-208.

Kellar KJ, Cascio CS, Bergstrom DA, Butler JA, Iadarola P (1981) Electroconvulsive shock and reserpine: effects on heta-adrenergic receptors in rat brain. $J$ Neurochem 37:830-836.

Kling A (1972) Effects of amygdaloidectomy on social affective behavior in non-human primates. In: Neurobiology of the amygdala (Eleftheriou BE, ed), pp 511-536. New York: Plenum.

Lindvall O, Bjorklund A, Divac I (1978) Organization of catecholamine neurons projecting to the frontal cortex in the rat. Brain Res 142:1-24.

Menkes DB, Aghajanian GK, Gallagher DW (1983) Chronic antidepressant treatment enhances agonist affinity of brain $\alpha-1$ adrenoceptors. Eur J Pharmacol 87:35-41.
Miach PJ, Dausse JP, Cadot A, Meyer P (1980) ${ }^{3} \mathrm{H}-$ Prazosin binds specifically to alpha-1 adrenoceptors in rat brain. Naunyn-Schmiedeberg's Arch Pharmacol 312:23-26.

Morrow AL, Creese I (1986) Characterization of alpha-1 adrenergic receptor subtypes in rat brain: a reevaluation of $\left[{ }^{3} \mathrm{H}\right] \mathrm{WB} 4101$ and $\left[{ }^{3} \mathrm{H}\right]$ prazosin binding. Mol Pharmacol 29:321-330.

Norman AB, Battaglia G, Creese I (1985) ${ }^{3} \mathrm{H}-W B 4101$ labels the 5-HT1A serotonin subtype in rat brain: guanine nucleotide and divalent cation sensitivity. Mol Pharmacol 28:487-494.

Nowak G, Przegalinski E (1988) Effect of repeated treatment with antidepressant drugs and electroconvulsive shock (ECS) on $\left[{ }^{3} \mathrm{H}\right]$ prazosin binding to different rat brain structures. J Neural Transm 71:57-64.

Parnavelas JG, Papadopoulos GC (1989) The monoaminergic innervation of cerebral cortex is not diffuse and nonspecific. Trends Neurosci 12:315-319.

Paxinos G, Watson C (1986) The rat brain in stereotaxic coordinates. 2nd ed. Sydney: Academic.

Rainbow TC, Biegon A (1983) Quantitative autoradiography of ${ }^{3} \mathrm{H}-$ prazosin binding sites in rat forebrain. Neurosci Lett 40:221-226.

Reyes-Vazquez D, Enna SJ, Dafny N (1986) The parafasciculus thalami as a site for mediating the antinociceptive response to GABAergic drugs. Brain Res 383:177-184.

Ruffolo RR, Waddell JE, Yaden EL (1982) Heterogeneity of postsynaptic alpha adrenergic receptors in mammalian aorta. J Pharmacol Exp Ther 221:309-314.

Stockmeier CA, McLesky SW, Blendy JA, Armstrong NR, Kellar KJ (1987) Electroconvulsive shock but not antidepressant drugs increases alpha- 1 adrenoceptor binding sites in rat brain. Eur J Pharmacol 139:259-266.

Swanson LW, Hartman BK (1975) The central adrenergic system: an immunofluorescence study of the location of cell bodies and their different connections in the rat utilizing dopamine- $\beta$-hydroxylase as a marker. J Comp Neurol 163:467-506.

Tallarida RJ, Jacobs LS (1979) The dose-response relation in pharmacology. New York: Springer-Verlag.

Unnerstall JR, Fernandez I, Orensanz LM (1985) The alpha-adrenergic receptor: radiohistochemical analysis of functional characteristics and biochemical differences. Pharm Biochem Behav 22:859-874.

Vetulani J, Antkiewicz-Michaluk L, Rokosz-Pelc A, Pilc A (1983) Chronic electroconvulsive treatment enhances the density of $\left[{ }^{3} \mathrm{H}\right.$ ]prazosin binding sites in the central nervous system of the rat. Brain Res 275:392-395.

Wilson KM, Minneman KP (1989) Regional variations in $\alpha$-1-adrenergic receptor subtypes in rat brain. J Neurochem 53:1782-1786. 